\author{
КОМПЛЕКСНАЯ МОРФОФИЗИОЛОГИЧЕСКАЯ \\ ХАРАКТЕРИСТИКА ИММУННОГО ЛИЗОСОМАЛЬНОГО \\ КАТИОННОГО БЕЛКА ЛЕЙКОЦИТОВ \\ В РАННЕМ ОНТОГЕНЕЗЕ БРОЙЛЕРНЫХ КУР \\ Е.А. Колесник ${ }^{1}$, М.А. Дерхо ${ }^{2}$, И.А. Лебедева ${ }^{1}$ \\ ${ }^{1}$ Уральский федеральный аграрный научно-исследовательский центр \\ Уральского отделения РАН, г. Екатеринбург, 620142, Россия \\ ${ }^{2}$ Южно-Уральский государственный аграрный университет, г. Троиик, 457100, Россия
}

\begin{abstract}
Аннотация
Определены катионные белки (КБ) в лизосомах полиморфноядерных лейкоцитов с использованием цитохимической реакции по М.Г. Шубичу и лейкограммы по А. Паппенгейму - в мазках, изготовленных из цельной крови цыплят-бройлеров кросса Hubbard ISA F15 (все исследованные особи были разделены на четыре группы $(n=10)$ в зависимости от возраст цыплят (P1, P7, Р23 и Р42): 1, 7, 23 и 42 сут постнатального онтогенеза) промышленного стада. Характеризовали морфологические изменения лизосом с катионными белками и рассчитывали комплексные морфофизиологические критерии катионных белков, исходя из известных в литературе и предложенных нами формул показателей, по выполненным микрофотографиям полиморфноядерных лейкоцитов (всего было изучено 855 микрофотографий). Так, у цыплят в первой декаде, с Р1 на Р7, регистрировался значительный рост содержания моноцитов - до $348.84 \%$, $p<0.05$ (второй пик увеличения числа моноцитов наблюдался от Р23 к Р42 - до 200\%, $p<0.05)$. С Р7 до Р23 отмечалось существенное уменьшение индексов соотношения гранулоцитов с дегранулированными и декатионизированными лизосомальными гранулами КБ (деГ/деКГрИ) - на $349.86 \%$, от $24.35 \pm 19.07$ до $6.96 \pm 4.75$ усл. ед. - и - уровня дегрануляции и декатионизации лизосомальных гранул КБ гранулоцитов (дег/деКV) на $278.57 \%$, от $12.48 \pm 9.49$ до $4.48 \pm 3.18$ усл. ед. Возраст с Р7 на Р23 отличался наиболее активным расходованием катионных белков, исходя из данных показателя заполнения клетки (ПЗК) и особенно интегрального цитохимического показателя (ИЦП), который снижался с Р1 к Р7 до 208.32\% - от $171.51 \pm 37.71$ до $82.33 \pm 20.85, p<0.05$. С третьей на четвёртую декаду, с Р23 к Р42, регистрировался существенный статистически значимый рост дег/декГрИ - до $496.41 \%$, от $6.96 \pm 4.75$ до $34.55 \pm 5.71$ усл. ед., $p<0.01$ - и деГ/ДЕК $\mathrm{V}$ - до $562.95 \%$, от $4.48 \pm 3.18$ до $25.22 \pm 6.88$ усл. ед., $p<0.05$, соответственно. При относительном сохранении расходования КБ с третьей на четвёртую декаду (Р23-P42), средний цитохимический коэффициент (СЦК) с Р23 к Р42 уменьшался на $25.29 \%$ - от $2.18 \pm 0.16$ до $1.74 \pm 0.14$ усл. ед., $p<0.05$. Кроме того, происходило активное восстановление паритета концентрации КБ до относительно высокого уровня в Р1. ИЦП в период с Р23 к Р42 возрастал до $181.86 \%$ - от $93.82 \pm 15.67$ до $170.62 \pm 21.99$ усл. ед., $p<0.01$. Можно заключить, что это является одним из звеньев восстановления и поддержания гомеостаза неспецифического иммунитета. Полученные нами комплексные данные по возрастной динамике катионных белков, в раннем онтогенезе цыплят бройлеров, могут служить основой разработки и апробации пробиотических и других фармацевтических препаратов с точечным, направленным действием сохранения здоровья птицы.
\end{abstract}


Ключевые слова: иммунные лизосомальные катионные белки, полиморфноядерные лейкоциты, дегрануляция и декатионизация, неспецифический иммунитет, цыплятабройлеры

\section{Введение}

Лизосомы гранулоцитов в совокупности своих функций участвуют в обеспечении постоянства внутренней среды клетки [1, с. 9]. Количественные и качественные изменения этих органоидов могут отражать степень интенсивности внутриклеточного обмена и, таким образом, являться морфофизиологическим выражением функциональной активности полиморфноядерных лейкоцитов (ПМЯЛ) или, наоборот, сигнализировать о нарушениях в работе гранулярных клеток крови $[1$, с. 9,10$]$.

Лизосомальные катионные белки (ЛКБ) ПМЯЛ играют важную роль в иммунологических процессах, определяют взаимосвязь в развитии клеточных и гуморальных факторов иммунитета, а также в формировании неспецифического и специфического звена резистентности, обеспечивая иммунный гомеостаз и, вследствие этого, развитие приспособления к условиям жизнедеятельности на всех стадиях онтогенеза [1-8]. Кроме того, ЛКБ ПМЯЛ принимают активное участие в бактериальном клиренсе, то есть в очищении тканей организма от патогенных бактерий [1-8].

Достоверно известна интегративная роль катионных белков (КБ) в механизмах иммунного гомеостаза: регуляции дифференциации миелоидных клеток-предшественников из костного мозга в моноциты и гранулоциты, в кровяном русле и тканях КБ гранулоцитов регулируют дифференцировку моноцитов в макрофаги, которые, в свою очередь, секретируют колониестимулирующие факторы стимуляции и ингибирования пролиферации гранулоцитов и моноцитов [3-7].

Изучение функциональной морфологии лизосом ПМЯЛ при выявлении в них КБ даёт весомый инструментарий для оценки неспецифической резистентности и взаимодействия клеточных систем в животном организме [1]. Известно, что неспецифическая резистентность организма - ведущий критерий потенциала здоровья животного, его способности к адаптогенезу [9-12].

Ранее были описаны азурофильные лизосомальные гранулы с катионными белками (ЛГКБ), появляющиеся на стадии промиелоцита, и специфические (псевдовторичные) ЛГКБ на стадии миелоцита $[1$, с. 8]. Азурофильные и специфические лизосомы с КБ в ПМЯЛ являются истинно первичными, поскольку они образуются в мембранах пластинчатого комплекса (ретикулюма) аппарата Гольджи $[1$, c. 8,9$]$. При этом истинно вторичными гранулами с КБ в ПМЯЛ можно считать только фаголизосомы (в связи с тем, что они образуются путём эндоцитоза и пиноцитоза, то есть дегрануляции (слияния) первичных азурофильных и специфических ЛГКБ) [1, с. 9]. Азурофильные и специфические (псевдовторичные) группы лизосом различаются, по составу, в основном содержанием некоторых катионных протеиновых ферментов; однако и в тех, и в других присутствуют неферментные катионные белки [1-4]. 
В литературе имеются некоторые данные [13-15] относительно концентрации КБ в ПМЯЛ у пород и кроссов кур яичного направления селекции, полученные в результате цитофизиологического изучения лизосом в гранулоцитах. Половые различия по содержанию ЛГКБ ПМЯЛ у птиц не выявлены [16].

На настоящий момент микрофотографии лизосом с катионными белками в лейкоцитах птицы в литературе отсутствуют $[13,15,16]$ или представлены единично с низким разрешением изображения [14] и отсутствием морфологической характеристики.

Для кур-бройлеров мясной селекции нам не удалось найти каких-либо подобных опубликованных данных.

Однако даже имеющиеся результаты, по яичным кроссам кур, были получены только методом подсчёта полуколичественного среднего цитохимического коэффициента (СЦК) [13-15], который ввиду значительной субъективности не характеризует в полной мере морфофизиологические проявления функциональной активности совокупности катионных белков в организме птицы.

Известны инструментальные объективные количественные методы цитохимического подсчёта содержания ЛКБ в гранулоцитах, основанные на интегральных индексах, включающих определение оптической плотности продукта цитохимической реакции, а соответственно, и физиологического состояния и уровня метаболизма катионных белков, площади лизосом с КБ, площади самих гранулоцитов [17]. Эти методы были успешно использованы в изучении ЛКБ ПМЯЛ у морских млекопитающих [17].

Тем не менее хотелось бы подчеркнуть, что применяемые СЦК и инструментальные количественные индексы только косвенно характеризуют вышеобозначенные физиологические функции клеток крови, а именно: микрофагальный фагоцитоз и регуляцию формирования макрофагов путём выявления динамики КБ только в самих клетках ПМЯЛ, без учёта ведущей роли в этих процессах нейтрофильных экстрацеллюлярных (внеклеточных) сетей (neutrophil extracellular traps, HBC) из вышедших в плазму крови лизосом с иммунными катионными белками $[5,7]$.

Решением данной проблемы является разработка морфофизиологических методов, включающих цитохимические показатели, характеризующие совокупность морфологических проявлений процессов дегрануляции и декатионизации катионных белков в полиморфноядерных лейкоцитах на стадиях завершения их жизни, в ходе $\mathrm{HBC}$ - опосредованной смерти гранулоцитов $[5,7]$.

В связи с этим целью настоящей работы явилась разработка морфофизиологических показателей, включающих цитохимические критерии оценки дегрануляции и декатионизации катионных белков полиморфноядерных гранулоцитов и совокупное их применение со средним цитохимическим коэффициентом и инструментальными цитохимическими количественными методами для комплексной характеристики иммунных лизосомальных катионных белков лейкоцитов в раннем онтогенезе бройлерных кур промышленного кросса.

\section{1. Материалы и методы исследования}

Исследования проведены в соответствии с принципами гуманного обращения с подопытными животными, изложенными в директивах Европейского Парла- 
мента и Совета ЕС по охране животных, используемых в научных целях (Директива 2010/63/EU).

Экспериментальная часть работы выполнена на ООО «Чебаркульская птица» (Чебаркульский р-н, Челябинская обл.). Объектом исследования служили бройлерные цыплята Gallus gallus (Linnaeus, 1758) кросса Hubbard F15 промышленного стада, из которых в цехе выращивания (клеточное содержание), согласно принципу сбалансированных групп, сформировали четыре группы $(n=10)$. Возраст цыплят в каждой из групп составил $1,7,23$ и 42 сут постнатального онтогенеза - P1, P7, P23 и Р42 соответственно. Кормление и содержание цыплят осуществляли в соответствии с зоогигиеническими нормами согласно рекомендациям (Руководство Hubbard ISA, URL: http://hubbardbreeders.com).

Материалом исследований служила цельная кровь, которую собирали в стандартизированные вакуумные пробирки с ЭДТА путём декапитации птицы в 1- и 7-суточном возрасте и прижизненно - пункцией подкрыльцовой вены у 23- и 42суточных цыплят [18]. Для выявления катионных белков в лизосомах полиморфноядерных лейкоцитов в мазках крови производили цитохимическую реакцию по М.Г. Шубичу в прописи Б.С. Нагоева с бромфеноловым синим $[1,16]$. Лейкограмму $(n=10)$ определяли в мазках крови, окрашенных по Паппенгейму (A. Pappenheim) [19].

Микрофотографии были получены с помощью большого биологического микроскопа («МББ - 1А», «ЛОМО», Россия), оснащенного микрографической окулярной видеокамерой с матрицей разрешением 5 мегапикселей (Full HD High resolution "HAYEAR" CMOS 5.0 Megapixel microscope video camera, KHP) с визуализацией в программе ToupView (ToupTek Photonics, KHP; релиз 2015 г., URL: http://www.touptek.com/) [20,21], с построенной светодиодной системой освещения микропрепаратов белым спектром (реализован принцип Кёлера) [20]. Применяли объектив масляной иммерсии 100-кратный с апертурой $1 / 25$ («ЛОМО», Россия). Калибровку видеокамеры производили по шкале объектамикрометра для проходящего света с ценой деления 0,01 мм («ОМП» ГОСТ 7513-55 «ЛОМО», Россия) в программе ToupView.

Цитоморфометрию и вычисление показателей осуществляли по микрофотографиям, произведённым в количестве, зависимом от абсолютного содержания гранулоцитов - в каждом мазке возрастной группы (P1, P7, Р23, Р42 по $n=5$ мазков в каждой группе); соответственно: Р1: $n=236$; Р7: $n=161$; Р23: $n=203$; Р42: $n=255$ - микрофотографий гранулоцитов. Совокупно, в исследуемых группах P1, Р7, P23, Р42 были проанализированы цитофизиологические показатели по 855 микрофотографиям.

В программе PhotoM 1.21 (Россия) [22-26] определяли оптическую плотность (денситометрию) $[22,23]$ лизосомальных катионных белков гранулоцитов $\left(D_{\text {лкьг }}\right)[17]$ - корректировку абсолютных числовых значений показателя оптической плотности осуществляли введением в расчёт поправочного коэффициента путём вычисления частного $D$ к $1:(1 / D)$, где $D$ - показатель оптической плотности продукта цитохимической реакции; 1 - поправочный коэффициент - и площадь гранулоцитов $\left(S_{\Gamma}\right)$, мкм² 
B программе ToupView определяли следующие показатели: диаметр лизосомальных гранул катионных белков гранулоцитов $\left(d_{\text {лгкь }}\right)$, мкм; площадь лизо-

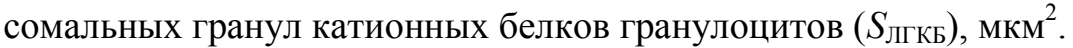

По полученным цитоморфологическим величинам вычисляли следующие показатели в программе Microsoft Office Excel 2007 (Microsoft Corporation, CША):

- минимальная и максимальная оптическая плотность лизосомальных ка-

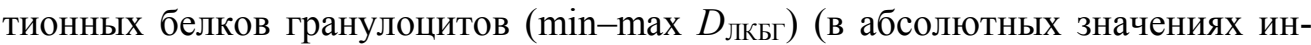
дивидуально по гранулам);

- минимальный и максимальный диаметр лизосомальных гранул катионных белков гранулоцитов ( $\min -\max d_{\text {лгкБ}}$ ), мкм (рассчитывается в абсолютных значениях индивидуально по гранулам);

- диаметр гранулоцитов $\left(d_{\Gamma}\right)$, мкм, вычисляли по формуле $d_{\text {г }}=2 \sqrt{S_{\Gamma} / \pi}$;

- показатель заполнения клетки (ПЗК), \%: ПЗК $=\frac{S_{\text {кб́ }}}{S_{\text {г }}} \cdot 100 \%$, где $S_{\text {кб }}-$ суммарная площадь продукта цитохимической реакции (лизосомальных катионных белков) в клетке, мкм²; $S_{\text {г }}$ площадь клетки (гранулоцита) [17];

- интегральный цитохимический показатель (ИЦП), усл. ед.: ИЦП $=\frac{S_{\text {кб }} D_{\text {кб }}}{100}$, где $S_{\text {кб }}-$ суммарная площадь продукта цитохимической реакции (лизосомальных катионных белков) в клетке, мкм ${ }^{2} ; D_{\text {кб }}-$ совокупная оптическая плотность продукта цитохимической реакции (лизосомальных катионных белков) в клетке; 100 - поправочный коэффициент [17];

- средний цитохимический коэффициент лизосомальных катионных белков гранулоцитов (СЦК лкьг), усл. ед. (по [1]):

СЦК $_{\text {лкьг }}=\frac{(0 \cdot a)+(1 \cdot b)+(2 \cdot c)+(3 \cdot d)+(4 \cdot e)}{N}$, где $a-$ отсутствие активности; $b$ - низкая активность (диффузное светло-голубое окрашивание цитоплазмы, иногда тусклые гранулы оттенков голубого цвета); $c$ - умеренная активность (хорошо выраженные гранулы светло-голубого, бирюзового, светло-синего цвета); $d$ - высокая активность (гранулы синего цвета в относительно большом количестве); $e$ - очень высокая активность (заполнение существенной части объёма цитоплазмы гранулами синего цвета); $N$ - общее количество учтенных гранулоцитов в мазке крови.

Для цитофизиологической характеристики процессов дегрануляции [2-5; 27$, с. 36] и декатионизации [2; 27, с. $36,37,39]$ лизосом, содержащих катионные белки, и оценки особенностей их метаболизма в полиморфноядерных лейкоцитах нами были предложены и рассчитаны следующие критерии:

- дегЛГКБ, \% - процент гранулоцитов с дегранулированными лизосо-

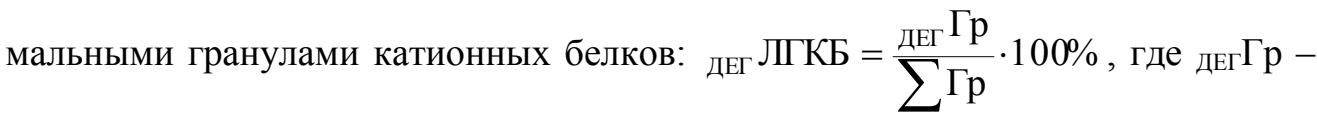
количество (абсолютное) гранулоцитов с дегранулированными лизосомальными гранулами катионных белков; $\sum$ р - суммарное (абсолютное) количество гранулоцитов; 
- декЛГКБ, \% - процент гранулоцитов с декатионизированными лизосомальными гранулами катионных белков: дек ЛГКБ $=\frac{\text { дек Гр }}{\sum} \Gamma \mathrm{p} \cdot 100 \%$, где декГр количество (абсолютное) гранулоцитов с декатионизированными лизосомальными гранулами катионных белков;

- дег/декГрИ, усл. ед. - индекс соотношения гранулоцитов с дегранулированными и декатионизированными лизосомальными гранулами катионных белков: дег/дек ГрИ $=\frac{\text { дЕГ Гр }}{\text { дЕГ Гр }} \cdot 100$;

- дег $\mathrm{V}, \%$ - уровень дегрануляции лизосомальных гранул катионных белков гранулоцитов в процентах: дег $\mathrm{V}=\frac{\text { дег } \mathrm{L}}{\sum \Gamma \mathrm{p}} \cdot 100 \%$, где дег $\mathrm{L}-$ степень дегрануляции лизосомальных гранул катионных белков в клетке, выражаемая в долях единицы (0.2-0.4-0.6-0.8-1);

- дек $\mathrm{V}, \%$ - уровень декатионизации лизосомальных гранул катионных

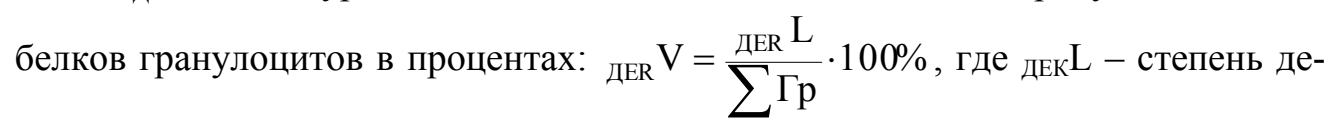
катионизации лизосомальных гранул катионных белков в клетке, выражаемая в долях единицы (0.2-0.4-0.6-0.8-1);

- дег/дек $\mathrm{V}$, усл. ед. - индекс уровня дегрануляции и декатионизации лизосомальных гранул катионных белков гранулоцитов: дег/дек $\mathrm{V}=\frac{\text { дЕГ } \mathrm{L}}{\text { дег } \mathrm{L}} \cdot 100$.

В программе ToupView определяли масштаб изображений и на микрофотографиях размещали масштабную линейку с ценой деления в 1 и 10 мкм соответственно.

Степень и достоверность различий для полученных результатов оценивали с помощью параметрического $t$-критерия Стьюдента для множественных парных сравнений с применением поправки Бонферрони в программе STATISTICA 8.0 (StatSoft, Inc., США). Критический уровень значимости различия значений при проверке статистических гипотез был принят за $p \leq 0.05$.

\section{2. Результаты и их обсуждение}

В целом по возрастной динамики Р1-P7-P23-P42 уровень формирования пула иммунных катионных белков в зависимости от количества и размера лизосомальных гранул с КБ в клетке в норме может весьма различаться (см. табл. 1, рис. 1-3): от заполнения существенного пространства цитоплазмы, не занятого ядром (рис. 1: $1.1,1.3-1.5$; рис. $2: 2.5,2.6)$ к постепенному синусоидальному снижению количества лизосом с катионными белками (табл. 1, рис. 2), вплоть до содержания единичных гранул в клетке (рис. 2: 2.2), и гранулоцитов, не содержащих лизосомы с иммунными катионными белками (рис. $2: 2.3$ ). 

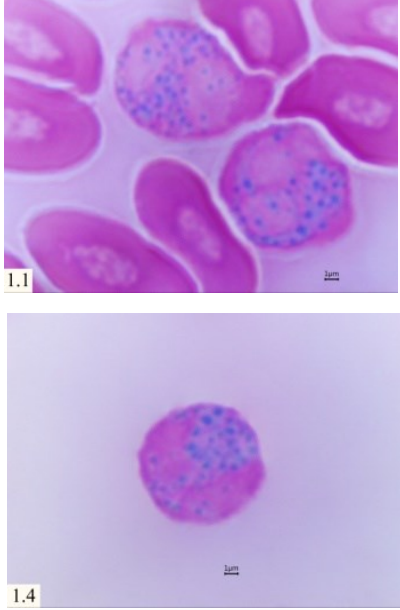
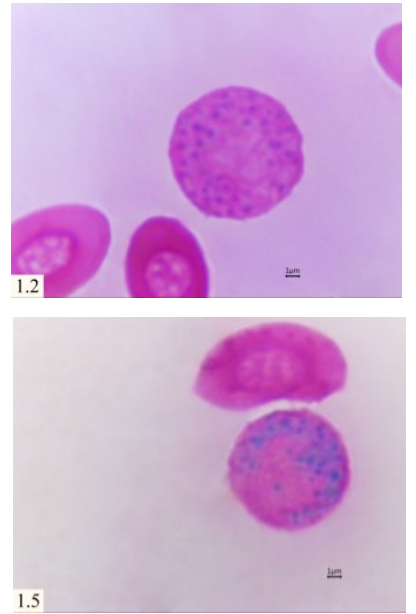
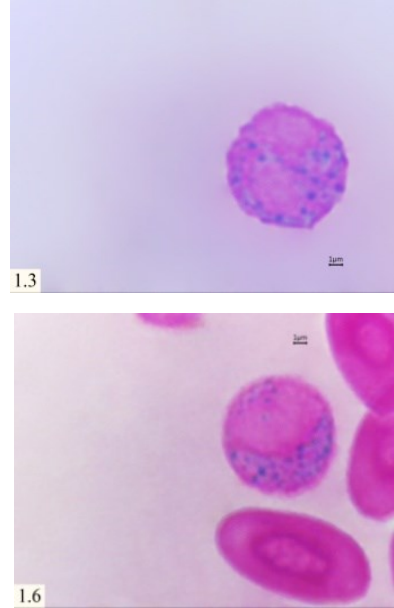

Рис. 1. Общая морфология лизосом с катионными белками полиморфноядерных лейкоцитов крови цыплят-бройлеров в возрасте: $1.1-1$ сут, $1.2-42$ сут, 1.3-1.6 - 1 сут (цитохимическая реакция с бромфеноловым синим на катионные белки с докрашиванием основным фуксином по М.Г. Шубичу)
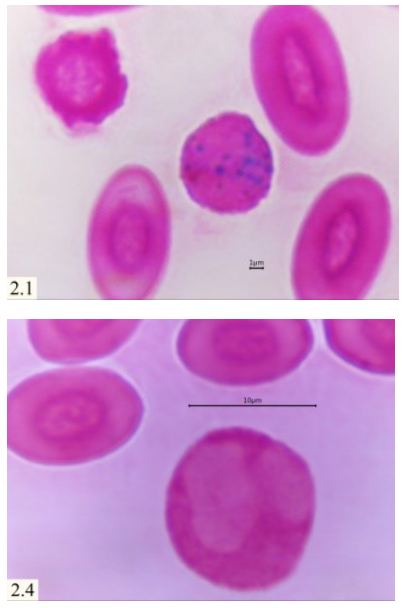

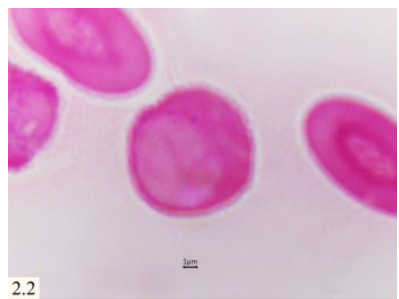

2.2

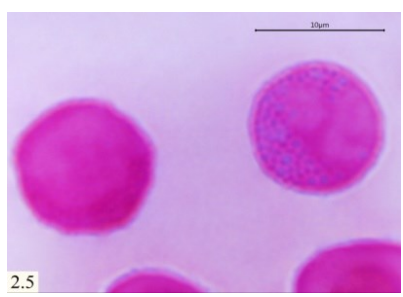

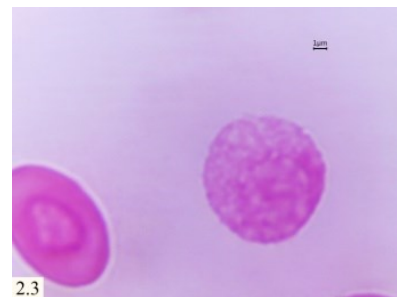

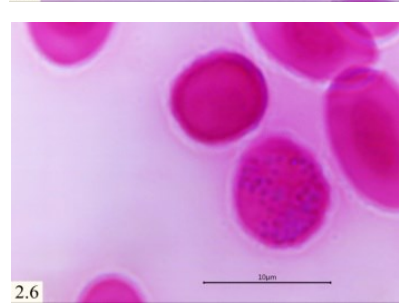

Рис. 2. Градация по количеству лизосом с катионными белками в полиморфноядерных лейкоцитах, сравнение гранулоцитов с лимфоцитами (агранулоцитами) и моноцитом крови у цыплят-бройлеров возраста: $2.1,2.2-1$ сут, $2.3-2.5-42$ сут, 2.6 - 23 сут (цитохимическая реакция с бромфеноловым синим на катионные белки с докрашиванием основным фуксином по М.Г. Шубичу)

На рис. 2 представлены гранулоциты: 2.5 и 2.6 с густо заполненной лизосомами цитоплазмой; лейкоцит 2.1 с существенно меньшим количеством лизосом в сравнении с клетками - 2.5 и 2.6; палочкоядерный гранулоцит 2.2 только с тремя слабовыраженными весьма мелкими лизосомами; гранулоцит 2.3 с полным отсутствием катионного белка в лизосомах.

Гранулоциты, не имеющие лизосом с катионными белками, имеют крупносетчатую цитоплазму, при детальном рассмотрении которой обнаруживаются просветы - контуры свободных гранул (рис. 2: 2.3). 

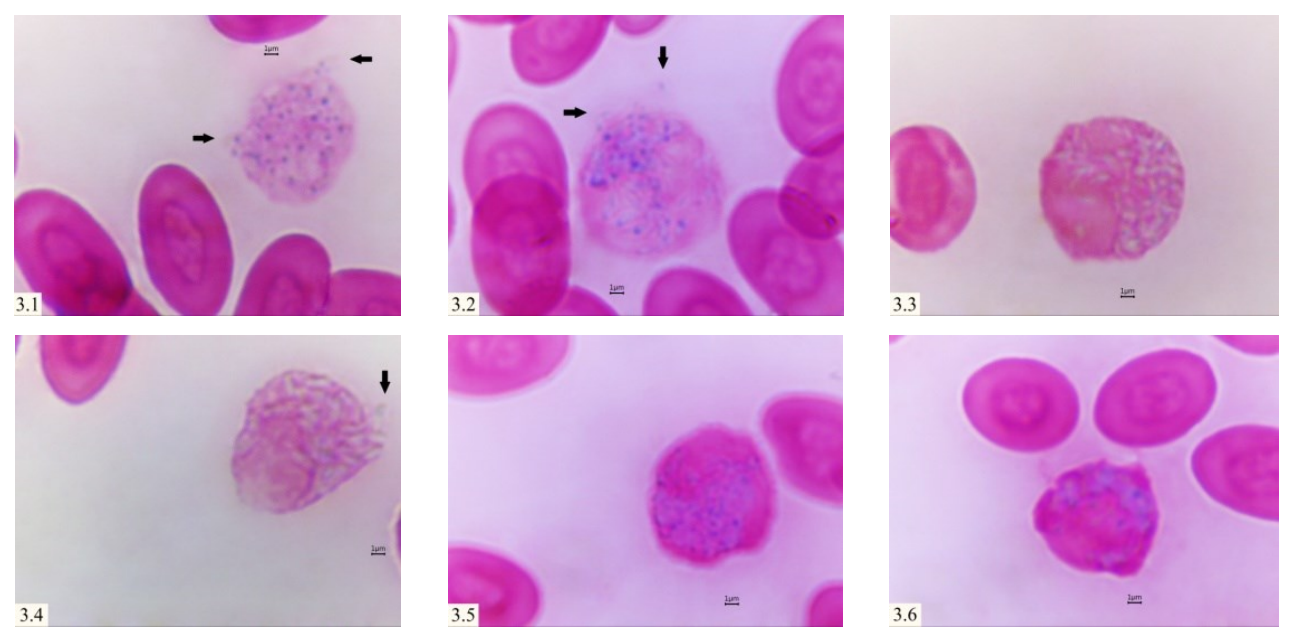

Рис. 3. Стадии декатионизации и дегрануляции лизосом с катионными белками полиморфноядерных лейкоцитов крови цыплят-бройлеров возраста: 3.1 - 1 сут, 3.2- 42 сут, $3.3,3.4-1$ сут, $3.5,3.6$ - 42 сут (цитохимическая реакция с бромфеноловым синим на катионные белки с докрашиванием основным фуксином по М.Г. Шубичу)

Размеры лизосом с КБ в ПМЯЛ в зависимости от стадий субклеточного метаболизма колеблются в широких пределах (рис. 1-3): с минимальным диаметром 0.23 мкм в Р7 и 0.24 мкм в Р23 и площадью 0.14 мкм $^{2}$ в Р7-P23 до наибольшего диаметра 1 мкм в Р1 и 1.02 мкм в Р42 и площади 0.25 мкм $^{2}$ в Р1 и 0.17 мкм $^{2}$ в Р42.

Гранулоциты с микрофотографий $(1.1,1.2)$ имеют лизосомы в основном равного размера (рис. 1). Лейкоцит 1.4 с выраженной дифференциацией калибра лизосом, при этом, лейкоциты: 1.3 и 1.4 с хорошо различимыми участками просветления вокруг самих гранул (декатионизация лизосом с катионными белками) (см. рис. 1).

Лизосомы в представленных лейкоцитах преимущественно округлой формы (рис. 1).

В ядрах гранулоцитов на фотографиях: $1.2,1.3$ и 1.5 визуализируются участки гетерохроматина (тёмные полосы, глыбки) и эухроматина (светлые участки) (рис. 1).

Необходимо отметить, что и в переделах каждой из возрастных групп отмечается существенный интервал в размерах лизосом: для Р42 разница в диаметре достигает 408\% (см. табл. 1). Это, во-первых, подчёркивает внутривозрастную индивидуальную изменчивость, а, во-вторых, весьма сложную физиологию лизосомальных катионных белков в организме цыплят-бройлеров, что, в принципе, объяснимо достаточно большой ролью данных биополимеров в иммунных процессах организма животных.

Имеются данные о морфологических особенностях лизосом с катионными белками ПМЯЛ [2], а именно: азурофильные в основном характеризуются более округлой формой, тогда как специфические зрелые лизосомы имеют вытянутую веретенообразную или неправильную форму. Кроме того, в данной работе отмечается, что образование лизосом с КБ может происходить практически в течение всех стадий жизни ПМЯЛ, в том числе и на уровне сегменто- 
ядерных клеток. В нашем исследовании лизосомы с КБ в гранулоцитах цыплятбройлеров в основном имеют округлую (рис. 1,2 ) или продолговатую веретенообразную форму (рис. 3: 3.2-3.4).

Морфофизиологические проявления метаболизма лизосомальных гранул с катионными белками, так и собственно катионных белков гранулоцитов, характеризуются процессами декатионизации (рис. 3: 3.1-3.4) [2; 27, с. 36, 37, 39] и дегрануляции лизосом, содержащих катионные белки (рис. $3: 3.5,3.6$ ), в течение всего периода жизнедеятельности гранулярных лейкоцитов $[2 ; 3-5 ; 7 ; 27$, c. 36]. Так, процесс декатионизации на субклеточном уровне представляет собой переход катионных белков из первичных и вторичных лизосом без повреждения мембран данных органоидов во внеклеточное пространство внутренней среды организма (рис. $3: 3.1-3.4$ ) [2; 27, с. $36 ; 37 ; 39]$. Данный процесс в разной степени активности свойственен гранулярным лейкоцитам и прежде всего нейтрофилам (гетерофилам) в течение всего периода их жизни от молодых, зрелых до синильных форм клеток $[1,5,7]$.

По результатам цитофизиологического субклеточного качественного (рис. 3: 3.1-3.4) и количественного анализа (табл. 1) были выделены четыре стадии декатионизации лизосомальных гранул катионных белков лейкоцитов. На четвёртой максимальной стадии наблюдался наибольший выход катионных белков за пределы лизосом и клеток соответственно, вплоть до практически полного освобождения гранул от катионных белков. В результате этого процесса, визуально гранулы выглядели наиболее осветленными, чаще бесцветными - как бы пустыми (рис. 3: 3.4). На третьей стадии также регистрировался выраженный выход катионных белков во внеклеточное пространство (рис. 3: 3.2, 3.3). При этом оставшееся содержимое гранул, в зависимости от концентрации и химического состава, соответственно совокупного водородного показателя (рН среды) катионных белков имело спектральную градацию от голубого, светло-голубого до бирюзового и блекло-бирюзового цветов (рис. 3: 3.2-3.4). Относительно менее выраженным умеренным высвобождением катионных белков за пределы клеток отличалась вторая стадия: лизосомы окрашивались чаще насыщенным голубым цветом (рис. $1: 1.3,1.4$; рис. $3: 3.1$ ). Минимальными признаками декатионизации отличались лизосомы на первой стадии с относительно равномерно заполненным по всему объёму содержимым глубокого синего или голубого цветов (рис. 1: 1.1).

Так, на рис. 3 представлены гранулоциты: 3.3 и 3.4 с почти полностью декатионизированными лизосомами - катионный белок очень слабо выражен с весьма мелкими гранулами, окрашен бледно-голубым и бирюзовым цветом (наименьшая концентрация катионного белка), при этом мембраны (границы) лизосом хорошо различимы, видна зона просветления вокруг гранул в лизосомах.

Лейкоцит с фотографии 3.2 также с выраженной декатионизацией: чётко различимы участки со сравнительно более крупными гранулами катионного белка синего и голубого цветов и зоны просветления (декатионизации) в лизосомах (рис. 3). Тем не менее у лейкоцита 3.2 декатионизация меньше выражена в сравнении с клетками 3.3 и 3.4 (см. рис. 3). Гранулоцит на фотографии 3.1 аналогично клетки 3.2 с декатионизацией лизосом, однако гранулы тёмносинего цвета (наибольшая концентрация катионного белка) (рис. 3). 
Форма лизосом гранулоцитов, в изображениях: 3.1 - 3.4 преимущественно продолговатая веретенообразная, характерная для специфических лизосом (см. рис. 3).

По самым последним данным, внеклеточное обезвреживание патогенных микроорганизмов характеризуется экстрацеллюлярной (за пределами клеток нейтрофилов) дегрануляцией ЛГКБ ПМЯЛ; соответственно, в результате этого процесса завершается жизнь и самих ПМЯЛ при образовании НВС [5, 7]. В данном случае проявляется микробицидная внеклеточная функция за счёт выхода лизосомальных гранул с не ферментными и ферментными катионными протеинами из ПМЯЛ в плазму внутренней среды организма в ходе иммунологического, в том числе воспалительного, процесса. Однако этот процесс может реализовываться и при отсутствии активных патогенов [5, 7]. В случае выхода ЛГКБ (при разрушении самих ПМЯЛ) в плазму крови, в отсутствии местных патогенов, данная образующаяся НВС из физиологически активных гранулярных КБ служит активатором и посредником целого комплекса реакций развития иммунитета в организме, в том числе формирования макрофагов из моноцитов $[3-5,7]$. Регистрировался выход лизосом с катионными белками в разные стадии их метаболизма за пределы гранулоцитов, которые, в свою очередь, при этом также могут находиться на разных периодах своего развития - от зрелых до синильных форм (рис. 3: 3.1, 3.2, 3.4).

Так, на микрофотографиях 3.1, 3.2 и 3.4 стрелками отмечен выход лизосом с катионными белками из нейтрофилов (гетерофилов) в плазму, это характерно при образовании НВС, в результате этого происходит НBC - опосредованное завершение жизни гранулоцитов (см. рис. 3).

Е.А. Венглинской и М.Г. Шубичем было установлено, что при фагоцитозе бактерий нейтрофилами в крови кроликов происходило уменьшение количества КБ и при этом отмечалось появление «размытости» лизосом с катионным белком, снижалась интенсивность окраски ЛГКБ ПМЯЛ [27, с. 36].

По результатам анализа проявления процесса дегрануляции лизосомальных гранул с катионными белками в крови цыплят-бройлеров, аналогично процессу декатионизации, были выделены четыре стадии в зависимости от выраженности растворения стенок лизосом и выхода содержимого гранул во внутриклеточное пространство. В четвёртую стадию выделяли клетки с абсолютным наибольшим количеством лизосом, имеющих растворённые стенки, и вышедшими в цитозоль катионными белками (рис. 3: 3.6). На данной стадии катионные белки образовывали в гиалоплазме гранулоцитов размытые «дымчатые» поля - участки, не имеющие чётких границ локализации с цветовой гаммой оттенков голубого цвета (рис. 3: 3.6).

Выраженное растворение стенок лизосом выделяли в третью стадию (рис. 3: 3.5). Умеренным растворением лизосом с выходом в цитоплазму клеток катионных белков отличались гранулоциты на второй стадии. Минимально дегранулированные клетки выделяли в первую стадию.

На рис. 3.5 и 3.6 представлены лейкоциты с дегранулированными лизосомами (рис. 3). При этом дегрануляция наиболее выражена в клетке 3.6: лизосомы неопределённый формы с размытыми границами (растворёнными мембранными) образуют сплошные «дымчатые» участки вместо выраженных гранул с катион- 
ным белком (см. рис. 3). Данная картина характерна для микрофагального фагоцитоза (лизосомы сливаясь, образуют фагосомы), местами видны оформленные округлые гранулы (рис. 3).

Методологическое подразделение стадийности декатионизации и дегрануляции позволило подчёркнуть динамику с пиковыми проявлениями процессов метаболизма лизосомальных гранул лейкоцитов с иммунными катионными белками. Однако в раннем онтогенезе птицы в большей мере регистрировались сочетанные (рис. 1: 1.5, 1.6), в том числе переходные, формы с преобладанием реакций выхода катионных белков во внеклеточное пространство внутренней среды организма или за пределы лизосом в гиалоплазму гранулоцитов.

В ходе дифференциальной морфологической диагностики лейкоцитов при данной цитохимической реакции (с бромфеноловым синим) и сопутствующим окрашивании клеток основным фуксином [1,27], прежде всего, обращает на себя внимание оптически более плотное окрашивание цитоплазмы и ядра у лимфоцитов (агранулоцитов) по сравнению с более светлым тоном у гранулоцитов (рис. $2: 2.5,2.6$ ). Так, на фотографиях 2.5 и 2.6 слева и сверху, соответственно, лимфоциты, имеющие оптически плотно окрашенную цитоплазму с крупным округлым ядром, в сравнении с гранулоцитами, расположенными справа и снизу (см. рис. 2).

Наиболее крупные клетки, встречающиеся в мазке, представлены в основном моноцитами, имеющими значительный насыщенный тон цитоплазмы (рис. 2: 2.4).

Изображённый моноцит с характерным крупнолопастным ядром (рис. 2: 2.4). При этом ядро моноцитов также более плотно окрашивается, чем у гранулоцитов, в норме оно несегментировано (рис. 2: 2.4). Однако необходимо учитывать то, что у птиц, в отличие от млекопитающих, ядра моноцитов в норме часто имеют двулопастную (рис. 2: 2.4) или многолопастную структуру, что важно в дифференциации сравнительно крупных гранулоцитов от средних моноцитов. Данные варианты были выражены особенно в возрасте Р42, нередко встречались в Р1.

Ранее, в результате анализа лизосомально-катионного теста и вычисления полуколичественного среднего цитохимического коэффициента (СЦК) [13-15] были получены некоторые сведения о физиологической возрастной динамике КБ гранулоцитов в крови кур яичного направления селекции.

У кур породы Белый леггорн кросса П-46 ( $n=3$ в каждой возрастной группе) в физиологических условиях (промышленного производства на птицефабрике) наблюдалась циклическая динамика КБ в ПМЯЛ в крови кур по возрастам от 1 до 9 мес. [13]. Так, в одномесячном возрасте уровень КБ составлял порядка 3.2 усл. ед., после этого происходило снижение содержания КБ до 2.0 усл. ед. отмеченное в трехмесячном возрасте, далее до пятимесячного возраста наблюдалась стабилизация динамики с концентрацией КБ в этом периоде 2.0-2.21.8 усл. ед. [13]. После периода стабилизации, к семимесячному возрасту отмечалось дальнейшее снижение концентрации КБ в ПМЯЛ до примерно 1.5 усл. ед., однако далее данная концентрация уровня ЛКБ в ПМЯЛ снова стабилизировалась вплоть до девятимесячного возраста с содержанием в этом периоде КБ около 1.5 усл. ед. [13]. В крови кур породы Хайсекс - коричневый (браун) - односуточного возраста содержание КБ в ПМЯЛ колебалось от 0.75 до 1.28 усл. ед. [14]. 
При этом к семисуточному возрасту регистрировалось снижение концентрации КБ до менее 1 усл. ед. [14]. Однако, далее, отмечался стабильный рост концентрации КБ в ПМЯЛ с достижением 1.6-2 усл. ед. в возрастном периоде 45-60 сут [14]. Схожие данные по этому кроссу яичных кур были получены в [15]. У односуточных цыплят (в физиологических условиях промышленного производства) содержание КБ в ПМЯЛ составило около $0.875-0.884$ усл. ед. К 28-м суткам отмечался рост содержания КБ в гранулоцитах, после этого регистрировалось дальнейшее увеличение концентрации КБ, вплоть до начала яйцекладки к 115-м суткам [15]. В более поздние возрастные периоды автор отмечала стабилизацию содержания КБ в ПМЯЛ. Однако при достижении пика яйценоскости было отмечено снижение концентрации КБ в гранулоцитах крови [15].

Таким образом, у различных кроссов кур даже общего направления селекции, а именно яичного, наблюдаются существенные различия в уровне активации ЛГКБ ПМЯЛ в некоторых периодах раннего и половозрелого онтогенеза. Однако при этом чётко регистрируется цикличность динамики с пиками максимальных и минимальных концентраций КБ, а также с периодами стабилизации содержания (КБ в гранулоцитах крови) - плато, отражающее общебиологическую взаимосвязь формирования полноценного неспецифического иммунитета, развития на его основе специфического иммунитета и затраты организмом иммунных ресурсов на процессы приспособления в каждом физиологическом возрастном периоде.

Фактически цикличность колебания ЛКБ ПМЯЛ в онтогенезе является одной из основ биохимического пластического и энергетического уравновешивания, иммунологического баланса, обеспечивающего формирования адаптационного гомеостаза и, следовательно, сохранения иммунного гомеостаза в организме животных.

Полученные нами результаты возрастного изменения содержания лейкоцитов в крови кур-бройлеров (P1, Р7, Р23, Р42) (табл. 1) в целом соответствуют приводимой в [28, с. 125] физиологической синусоидной динамике лейкоцитов в искомые возрастные периоды, а также нормативным данным [29, p. 70].

По нашим данным, у цыплят-бройлеров возрастной период со второй на третью декаду, с Р7 на Р23, отличался интенсивным задействованием КБ на внеклеточные иммунные процессы, в основе которых лежат макрофагальное построение (рис. 3: 3.1, 3.2, 3.4), активизация тучных клеток. Следовательно, происходило развитие регуляции провоспалительных процессов. Так, в первой декаде, с P1 на Р7 регистрировалась начальная волна значительного роста содержания моноцитов до $348.84 \%, p<0.05$, (второй пик увеличения числа моноцитов наблюдался от Р23 к Р42, рост составил до $200 \%, p<0.05$, см. табл. 1). С P7 к Р23 отмечалось существенное (хотя и статистически не значимое, что, однако, можно объяснить сложным характером взаимоотношения процессов) уменьшение дег/декГрИ и дег/дек $\mathrm{V}$ на $349.86 \%$ и $278.57 \%$ соответственно (табл. 1 , рис. 3: 3.1, 3.2, 3.4). Данные процессы характеризуют неспецифическую адаптационную реакцию резервной адаптации и подготовки к форсированным физиолого-биохимическим изменениям $[10,11]$. 
Табл. 1

Лейкоформула и лизосомальный катионный белок лейкоцитов в раннем постнатальном онтогенезе бройлерных кур кросса Hubbard F15 ( $X \pm \mathrm{SEM}, n=10)$

\begin{tabular}{|c|c|c|c|c|}
\hline \multirow{2}{*}{ Показатель } & \multicolumn{4}{|c|}{ Возраст, сутки } \\
\hline & 1 & 7 & 23 & 42 \\
\hline \multicolumn{5}{|c|}{ Лейкограмма } \\
\hline Лимфоциты, \% & $35.50 \pm 1.24$ & $69.00 \pm 2.62^{*}$ & $50.20 \pm 2.28^{*}$ & $54.80 \pm 5.32$ \\
\hline Моноциты, \% & $0.86 \pm 0.34$ & $3.00 \pm 0.87^{*}$ & $2.00 \pm 0.45$ & $4.00 \pm 0.70^{*}$ \\
\hline Гетерофилы, \% & $60.40 \pm 1.25$ & $24.30 \pm 2.91^{*}$ & $44.90 \pm 1.88^{*}$ & $37.40 \pm 5.89$ \\
\hline Эозинофилы, \% & $1.29 \pm 0.29$ & $2.63 \pm 0.60^{*}$ & $2.30 \pm 0.33$ & $2.70 \pm 0.62$ \\
\hline Базофилы, \% & $2.00 \pm 0.31$ & $0.88 \pm 0.40^{*}$ & $0.60 \pm 0.31$ & $1.10 \pm 0.35$ \\
\hline \multicolumn{5}{|c|}{ Цитофизиологические показатели } \\
\hline $\min -\max \mathrm{d}_{\text {ЛГКБ}}$, мКм & $0.33-1$ & $0.23-0.79$ & $0.24-0.78$ & $0.25-1.02$ \\
\hline$d_{\text {ЛГКБ }}$, МКМ & $0.55 \pm 0.003$ & $0.42 \pm 0.002^{*}$ & $0.42 \pm 0.002$ & $0.46 \pm 0.002^{*}$ \\
\hline$d_{\Gamma}$, мКм & $8.45 \pm 0.19$ & $7.97 \pm 0.17$ & $9.03 \pm 0.15^{*}$ & $9.73 \pm 0.17^{*}$ \\
\hline$S_{\text {ЛГКБ }}$, мКм $^{2}$ & $0.25 \pm 0.003$ & $0.14 \pm 0.001^{*}$ & $0.14 \pm 0.001$ & $0.17 \pm 0.001^{*}$ \\
\hline$S_{\Gamma}$, мкм $^{2}$ & $57.49 \pm 2.58$ & $50.99 \pm 2.18$ & $64.87 \pm 2.11^{*}$ & $75.42 \pm 2.49^{*}$ \\
\hline $\min -\max D_{\text {ЛКБг }}$ & $8.93-8771.93$ & $4.52-6756.76$ & $5.56-7751.94$ & $10.31-8849.56$ \\
\hline$D_{\text {ЛКБГ }}$ & $156.40 \pm 19.48$ & $141.84 \pm 19.56$ & $108.49 \pm 12.87^{*}$ & $164.64 \pm 16.67^{*}$ \\
\hline ПЗК, \% & $9.07 \pm 0.68$ & $7.64 \pm 0.41$ & $6.80 \pm 0.28$ & $7.13 \pm 0.33$ \\
\hline ИЦП, усл. ед. & $171.51 \pm 37.71$ & $82.33 \pm 20.85^{*}$ & $93.82 \pm 15.67$ & $170.62 \pm 21.99^{*}$ \\
\hline СЦК & $2.23 \pm 0.17$ & $2.09 \pm 0.18$ & $2.18 \pm 0.16$ & $1.74 \pm 0.14^{*}$ \\
\hline деГЛГКБ, \% & $10.48 \pm 4.20$ & $2.79 \pm 1.19$ & $3.97 \pm 2.74$ & $17.69 \pm 5.11^{*}$ \\
\hline дЕКЛГКБ, \% & $51.38 \pm 12.00$ & $24.50 \pm 8.45$ & $38.99 \pm 8.12$ & $50.35 \pm 8.78$ \\
\hline ДЕГ/ДЕКГрИ, усл. ед. & $20.28 \pm 5.66$ & $24.35 \pm 19.07$ & $6.96 \pm 4.75$ & $34.55 \pm 5.71^{*}$ \\
\hline ДЕГ $\mathrm{V}, \%$ & $3.21 \pm 1.21$ & $0.68 \pm 0.33^{*}$ & $0.95 \pm 0.64$ & $6.03 \pm 2.49^{*}$ \\
\hline дЕК $\mathrm{V}, \%$ & $24.45 \pm 7.03$ & $10.37 \pm 4.16$ & $14.34 \pm 3.64$ & $22.00 \pm 4.00$ \\
\hline ДЕГ/ДЕК $\mathrm{V}$, Усл. ед. & $14.53 \pm 4.25$ & $12.48 \pm 9.49$ & $4.48 \pm 3.18$ & $25.22 \pm 6.88^{*}$ \\
\hline
\end{tabular}

Уровень значимости различия средних значений показателей определён по методу множественного парного сравнения с введением поправки Бонферрони $(p=0.05 / 3=0.017)$, соответственно: $*$ - достоверное отличие средних величин в множественном парном сравнении при $p \leq 0,017$.

Приспособительная реакция организма с P7 на Р23 сопровождалась и была обусловлена наиболее активным расходованием катионных белков за весь период Р1-Р42, исходя из данных ПЗК и особенно ИЦП, который снижался с Р1 к Р7 до $208.32 \%, p<0.05$ (табл. 1). Реакции в совокупности обеспечивают формирование регуляции и поддержание иммунного гомеостаза.

Далее, с третьей на четвёртую декаду, с Р23 к Р42, отмечалось переключение расхода КБ на внутриклеточные иммунные процессы в гранулоцитах и прежде всего гетерофилов, то есть на микрофагальные реакции (рис. 3: 3.5, 3.6) характеризующие активные разнонаправленные адаптации [10,11]. Так, регистрировался существенный статистически значимый рост дег/декГрИ и дег/дек $\mathrm{V}$ до $496.41 \%, p<0.01$ и $562.95 \%, p<0.05$, соответственно (табл. 1). Это сопровождается в периоде от Р23 к Р42 началом уравновешивания гранулоцитарного и агранулоцитарного рядов белого ростка системы крови, о чём свидетельствует ранее установленная нами [11] относительная стабильность интегрального соотношения эритроцитов, гетерофилов, лимфоцитов и кортизола (индекса ИИЭГЛК) в третью и четвёртую декады (табл. 1; рис. 3). В этом ключе необходимо отметить следующее. Было показано, что кортикостероиды (в том числе 
кортизол) участвуют в дестабилизации мембран лизосом с КБ в ПМЯЛ, то есть способствуют дегрануляции лизосом в ходе микрофагального (в нейтрофилах) фагоцитоза [27, с. 39]. При этом важным моментом является то, что при относительном сохранении расходования КБ в период с третьей на четвёртую декаду (Р23-Р42) (см. в табл. 1: ПЗК и СЦК в этот период) СЦК с Р23 к Р42 уменьшался на $25.29 \%, p<0.05$, происходило активное восстановление паритета концентрации КБ к относительно высокому уровню в Р1 (см. ИЦП в Р42 и Р1), ИЦП с Р23 к Р42 возрастал до $181.86 \%, p<0.01$ (табл. 1). Учитывая ранее полученные результаты $[10,11]$, можно заключить, что это является одним из звеньев восстановления и поддержания гомеостаза неспецифического иммунитета в данном периоде: от Р23 к Р42. Происходит стабилизирующий адаптационный процесс, развиваются неспецифические адаптационные реакции первичной стабилизации $[10,11]$.

\section{Заключение}

Таким образом, нами были разработаны морфофизиологические показатели, включающие оригинальные цитохимические критерии оценки дегрануляции и декатионизации катионных белков полиморфноядерных гранулоцитов, и осуществлено совокупное их применение со средним цитохимическим коэффициентом и инструментальными цитохимическими количественными методами для комплексной характеристики иммунных лизосомальных катионных белков лейкоцитов в раннем онтогенезе бройлерных кур промышленного кросса.

Была дана всесторонняя морфологическая характеристика метаболизма лизосом с катионными белками в лейкоцитах крови у цыплят-бройлеров промышленного кросса в неонатальном онтогенезе.

Полученные нами комплексные данные по возрастной динамике катионных белков в раннем онтогенезе цыплят бройлеров могут служить основой разработки и апробации пробиотических и других фармацевтических препаратов с точечным, направленным действием сохранения здоровья птицы, в условиях неизбежных экзогенных и эндогенных технологических стрессов, связанных как собственно с технологиями, так и с самой конституцией мясной птицы, а также с ростом скелетной мускулатуры, опережающим развитие внутренних органов.

\section{Литература}

1. Нагоев Б.С. Очерки о нейтрофильном гранулоците. - Нальчик: Эльбрус, 1986. - 144 с.

2. Borregaard N., Cowland J.B. Granules of the human neutrophilic polymorphonuclear leukocyte // Blood. - 1997. - V. 89, No 10. - P. 3503-3521. - doi: 10.1182/blood.V89.10.3503.

3. Soehnlein O., Weber C., Lindbom L. Neutrophil granule proteins tune monocytic cell function // Trends Immunol. - 2009. - V. 30, No 11. - P. 538-546. - doi: 10.1016/j.it.2009.06.006.

4. Soehnlein O., Lindbom L., Weber C. Mechanisms underlying neutrophil-mediated monocyte recruitment // Blood. - 2009. - V. 114, No 21. - P. 4613-4623. - doi: 10.1182/blood-200906-221630.

5. Mocsai A. Diverse novel functions of neutrophils in immunity, inflammation, and beyond // J. Exp. Med. - 2013. - V. 210, No 7. - P. 1283-1299. - doi: 10.1084/jem.20122220. 
6. Sheshachalam A., Srivastava N., Mitchell T., Lacy P., Eitzen G. Granule protein processing and regulated secretion in neutrophils // Front. Immunol. - 2014. - V. 5. Art. 448, P. 1-11. - doi: 10.3389/fimmu.2014.00448.

7. Нестерова И.В., Колесникова Н.В., Чудилова Г.А., Ломтатидзе Л.В., Ковалева С.В., Евглевский A.A. Нейтрофильные гранулоциты: новый взгляд на «старых игроков» на иммунологическом поле // Иммунология. - 2015. - Т. 36, № 4. - С. 257-265.

8. Mantripragada K.C., Quesenberry P.J. Polarization of neutrophil granules - a characteristic of inflammatory states // Blood Cells, Mol., Dis. - 2018. - No 69. - P. 74. - doi: 10.1016/j.bcmd.2017.09.008.

9. Галочкин В.A., Черепанов Г.Г. Неспецифическая резистентность продуктивных животных: трудности идентификации, проблемы и пути решения // Проблемы биологии продуктивных животных. - 2013. - № 1. - С. 5-29.

10. Kolesnik E.A., Derkho M.A. Involvement of cholesterol, progesterone, cortisol and lipoproteins in metabolic changes during early ontogenesis of broiler chicks of an industrial cross // S-kh. Biol. [Agric. Biol.]. - 2017. - V. 52, No 4. - P. 749-756. - doi: 10.15389/agrobiology.2017.4.749eng.

11. Колесник E.А., Дерхо М.А. Об участии гипофизарно-адренокортикальных гормонов в регуляции клеточного пула крови у цыплят-бройлеров // Проблемы биологии продуктивных животных. - 2018. - № 1. - С. 64-74. - doi: 10.25687/19966733.prodanimbiol.2018.1.64-74.

12. Новикова М.В., Лебедева И.А., Дроздова Л.И. Снижение риска патологий репродуктивной системы петухов при использовании пробиотика Моноспорин // Птица и птицепродукты. - 2018. - № 3. - С. 56-57. - doi: 10.30975/2073-4999-2018-20-3-56-57.

13. Кляикая Ю.В. Сравнительная морфология органов иммунитета кур породы белый леггорн кросса П-46 при применении различных доз препаратов «Комбиолакс» и «Сувар»: Автореф. дис. ... канд. биол. наук. - Саранск, 2008. - 20 с.

14. Турицына Е.Г. Оценка метаболической активности лейкоцитов птиц в постнатальном онтогенезе и при вирусных антигенных воздействиях // Аграрный вестн. Урала. 2009. - Т. 61, № 7. - С. 76-79.

15. Клетикова Л.В. Значение мониторирования уровня катионных белков у кур в условиях промышленного птицеводства // Морфология. - 2014. - Т. 145, № 3. - С. 94.

16. Дробот Г.П., Забиякин В.А., Степанова А.Е., Смоленцев С.Ю. Динамика цитохимических показателей псевдоэозинофилов крови цесарок // Рос. с.-х. наука. - 2017. № 1. - C. 42-44.

17. Минзюк Т.В., Кавцевич Н.Н. Бактерицидный катионный белок в лейкоцитах морских млекопитающих // Вестн. Мурм. гос. техн. ун-та. - 2013. - Т. 16, № 3. C. 506-511.

18. Owen J.C. Collecting, processing, and storing avian blood: A review // J. Field Ornithol. 2011. - V. 82, No 4. - P. 339-354. - doi: 10.1111/j.1557-9263.2011.00338.x.

19. Mulisch M., Welsch U. (Hrsg.) Romeis - Mikroskopische Technik. - Berlin, Heidelberg: Springer Spektrum, 2015. - xviii, 603 S. - doi: 10.1007/978-3-642-55190-1.

20. Markaki Y., Harz H. (Eds.) Light microscopy. Methods and protocols // Methods in Molecular Biology. - N. Y.: Humana Press, 2017. - V. 1563. - xi, 285 p. - doi: 1.1007/978$1-4939-6810-7$.

21. Кириллова И.А., Кириллов Д.В. Репродуктивная биология Platanthera bifolia (L.) Rich. (Orchidaceae) на северной границе ареала (Республика Коми) // Вестн. Том. гос. ун-та. Биология. - 2017. - № 38. - С. 68-88. - doi: 10.17223/19988591/38/4. 
22. Беляков A.B. Роль метаботропных глутаматных рецепторов I группы в формировании толерантности нейронов мозга к гипоксии: Автореф. дис. ... канд. биол. наук. СПб., 2010. - 22 с.

23. Комарова А.С. Изменение оптической плотности ядер миосимпластов в ходе эмбрионального развития // Вопросы морфологии XXI века. Вып. 3: Сб. науч. тр. «Актуальные вопросы преподавания морфологических дисциплин с использованием современных технологий. Фундаментальные и прикладные проблемы гистологии» (220 лет со дня рож. проф. МХА К.М. Бэра) / Под ред. И.А. Одинцовой, С.В. Костюкевича. - СПб.: ДЕАН, 2012. - С. 60-62.

24. Dimitrov V., Georgiev $G$. Study behavior of certain parameters affecting accuracy of geometric shape of the workpiece using photogrammetry // Int. Conf. on Technics, Technologies and Education ICTTE 2013. Oct. 30-31, 2013. - Yambol, Bulgaria, 2013. P. 1-8. - URL: https://sites.google.com/a/trakia-uni.bg/ictte-2013/.

25. Мужикян А.А., Иванов В.С. Особенности гистологического строения щитовидной железы собаки и морфология С-клеток на разных стадиях онтогенеза // Актуальные вопр. ветеринарной биол. - 2015. - № 3. - С. 12-21.

26. Соколова И.Б., Польнщев Д.Г. Эффективность применения мезенхимных стволовых клеток для улучшения микроциркуляции в коре головного мозга спонтанно гипертензивных крыс // Цитология. - 2017. - Т. 59, № 4. - С. 279-284.

27. Нагоев Б.С. Катионный белок лейкоцитов и его значение. Методические указания. Нальчик: Изд-во Кабард.-Балкар. гос. ун-а, 1982. - 68 с.

28. Кудрявцев А.А., Кудрявцева Л.А., Привольнев Т.И. Гематология животных и рыб. М.: Колос, 1969. - 320 с.

29. Campbell T.W., Grant K.R. Clinical Cases in Avian and Exotic Animal Hematology and Cytology. - Ames, Iowa: Wiley-Blackwell, 2010. - 392 p.

Поступила в редакцию 04.02.19

\footnotetext{
Колесник Евгений Анатольевич, кандидат биологических наук, старший научный сотрудник

Уральский федеральный аграрный научно-исследовательский центр Уральского отделения Российской академии наук ул. Белинского, д. 112 А, г. Екатеринбург,620142, Россия

E-mail: evgeniy251082@mail.ru
}

Дерхо Марина Аркадьевна, доктор биологических наук, профессор, заведующий кафедрой Института ветеринарной медицины
Южно-Уральский государственный аграрный университет ул. Гагарина, д. 13, г. Троицк, 457100, Россия
E-mail:derkho2010@yandex.ru

Лебедева Ирина Анатольевна, доктор биологических наук, ведущий научный сотрудник, заведующий отделом

Уральский федеральный аграрный научно-исследовательский центр Уральского отделения Российской академии наук ул. Белинского, д. 112 А, г. Екатеринбург,620142, Россия

E-mail:ialebedeva@yandex.ru 


\title{
UCHENYE ZAPISKI KAZANSKOGO UNIVERSITETA. SERIYA ESTESTVENNYE NAUKI
}

(Proceedings of Kazan University. Natural Sciences Series)

2019, vol. 161, no. 3, pp. 440-458

\author{
doi: 10.26907/2542-064X.2019.3.440-458 \\ Comprehensive Morphophysiological Description \\ of the Immune Lysosomal Cationic Protein of Leukocytes \\ in the Early Ontogeny of Broiler Chickens \\ E.A. Kolesnik ${ }^{\mathrm{a}^{*}}$, M.A. Derkho ${ }^{\text {b** }}$, I.A. Lebedeva ${ }^{\mathrm{a}^{* * *}}$ \\ ${ }^{a}$ Ural Federal Agricultural Scientific Research Center, Ural Branch, Russian Academy of Sciences, \\ Yekaterinburg, 620142 Russia \\ ${ }^{\mathrm{b}}$ South Ural State Agrarian University, Troitsk, 457100 Russia \\ E-mail: ${ }^{*}$ evgeniy251082@mail.ru, ${ }^{* *}$ derkho2010@yandex.ru, ${ }^{* * *}$ ialebedeva@yandex.ru
}

Received February 4, 2019

\begin{abstract}
Cationic proteins (CP) in the lysosomes of polymorphonuclear leukocytes were identified using the cytochemical reaction according to M.G. Shubitch and the leucogram as suggested by A. Pappenheim - in the smear samples made from the whole blood of broiler chickens of the Hubbard ISA F15 cross (all chickens were divided into four groups $(n=10)$ depending on their age (P1, P7, P23, and P42): days 1, 7, 23, and 42 of postnatal ontogeny) of the industrial herd. Morphological changes in the lysosomes with cationic proteins were characterized. Complex morphophysiological criteria of the cationic proteins were calculated based on the formulas from the literature and those proposed by us for the microphotographs of polymorphonuclear leukocytes (a total of 855 microphotographs were analyzed). Thus, during the first ten days, from $\mathrm{P} 1$ to $\mathrm{P} 7$, a significant increase in the monocyte content was registered - up to $348.84 \%, p<0.05$. The second peak in the number of monocytes was observed from P23 to $\mathrm{P} 42$ - up to $200 \%, p<0.05$. From $\mathrm{P} 7$ to $\mathrm{P} 23$, a significant decrease took place in the indices showing the ratio of granulocytes with degranulated and decationized lysosomal granules of CP (DEG/DECGrI) by $349.86 \%$ - from $24.35 \pm 19.07$ conv. units up to $6.96 \pm 4.75$ conv. units - and the level of degranulation and decationization of lysosomal granules in $\mathrm{CP}$ of granulocytes $(\mathrm{DEG} / \mathrm{DEC} \mathrm{V})$ by $278.57 \%$ - from $12.48 \pm 9.49$ conv. units to $4.48 \pm 3.18$ conv. units. From P7 to P23, the most active use of cationic proteins over the entire P1-P42 period occurred: based on of the cell fill factor (CFF) and, especially, the integral cytochemical index (ICI) that decreased from P1 to P7 by $208.32 \%$ - from $171.51 \pm 37.71$ conv. units to $82.33 \pm 20.85$ conv. units $p<0.05$. In the period from P23 to P42, a statistically significant increase in ${ }_{\mathrm{DEG} / \mathrm{DEC}}$ GrI by $496.41 \%$ - from $6.96 \pm 4.75$ conv. units up to $34.55 \pm 5.71$ conv. units, $p<0.01$ - and ${ }_{\mathrm{DEG} / \mathrm{DEC} V} \mathrm{~V}$ by $562.95 \%$ - from $4.48 \pm 3.18$ conv. units up to $25.22 \pm 6.88$ conv. units $p<0.05$ - was registered. With the relatively stable CP consumption from P23 to P42, the mean cytochemical coefficient (MCC) in this period decreased by $25.29 \%$ - from $2.18 \pm 0.16$ conv. units up to $1.74 \pm 0.14$ conv. units, $p<0.05$. In addition, the parity of $\mathrm{CP}$ concentration actively recovered to the level of P1; the ICI value from P23 to P42 increased by $181.86 \%$ - from $93.82 \pm 15.67$ conv. units up to $170.62 \pm 21.99$ conv. units, $p<0.01$. This can be considered as one of the links in the restoration and maintenance of the homeostasis of nonspecific immunity. The complex data obtained by us on the age dynamics of cationic proteins in the early ontogeny of broiler chickens can serve as a basis for further development and testing of probiotics and other pharmaceutical preparations for poultry with direct action.
\end{abstract}

Keywords: immune lysosomal cationic proteins, polymorphonuclear leukocytes, degranulation and decathionization, nonspecific immunity, broiler chickens

\section{Figure Captions}

Fig. 1. General morphology of lysosomes with cationic proteins of polymorphonuclear leukocytes in the blood of broiler chickens at the following age: 1.1 - day 1, 1.2 - day 42, 1.3-1.6 - day 1 (cyto- 
chemical reaction with bromphenol blue to cationic proteins, staining with basic fuchsin according to M.G. Shubich).

Fig. 2. Gradation based on the number of lysosomes with cationic proteins in the polymorphonuclear leukocytes, comparison of granulocytes with lymphocytes (agranulocytes) and monocytes in the blood in broiler chickens: 2.1, 2.2 - day 1, 2.3-2.5 - day 42, 2.6 - day 23 (cytochemical reaction with bromphenol blue to cationic proteins, staining with basic fuchsin according to M.G. Shubich).

Fig. 3. Decationization and degranulation of lysosomes with cationic proteins of polymorphonuclear leukocytes in the blood of broiler chickens at the following age: 3.1 - day $1,3.2$ - day 42, 3.3, $3.4-$ day $1,3.5,3.6$ - day 42 (cytochemical reaction with bromphenol blue to cationic proteins, staining with basic fuchsin according to M.G. Shubich).

\section{References}

1. Nagoev B.S. Ocherki o neitrofil'nom granulotsite [Essays on Neutrophilic Granulocyte]. Nalchik, El'brus, 1986. 144 p. (In Russian)

2. Borregaard N., Cowland J.B. Granules of the human neutrophilic polymorphonuclear leukocyte. Blood, 1997, vol. 89, no. 10, pp. 3503-3521. doi: 10.1182/blood.V89.10.3503.

3. Soehnlein O., Weber C., Lindbom L. Neutrophil granule proteins tune monocytic cell function. Trends Immunol., 2009, vol. 30, no. 11, pp. 538-546. doi: 10.1016/j.it.2009.06.006.

4. Soehnlein O., Lindbom L., Weber C. Mechanisms underlying neutrophil-mediated monocyte recruitment. Blood, 2009, vol. 114, no. 21, pp. 4613-4623. doi: 10.1182/blood-2009-06-221630.

5. Mocsai A. Diverse novel functions of neutrophils in immunity, inflammation, and beyond. J. Exp. Med., 2013, vol. 210, no. 7, pp. 1283-1299. doi: 10.1084/jem.20122220.

6. Sheshachalam A., Srivastava N., Mitchell T., Lacy P., Eitzen G. Granule protein processing and regulated secretion in neutrophils. Front. Immunol., 2014, vol. 5, art. 448, pp. 1-11. doi: 10.3389/fimmu.2014.00448.

7. Nesterova I.V., Kolesnikova N.V., Chudilova G.A., Lomtatidze L.V., Kovaleva S.V., Evglevsky A.A. Neutrophilic granulocytes: A new look at "old players" on the immunological field. Immunologiya, 2015, vol. 36, no. 4, pp. 257-265. (In Russian)

8. Mantripragada K.C., Quesenberry P.J. Polarization of neutrophil granules - a characteristic of inflammatory states. Blood Cells, Mol., Dis., 2018, no. 69, pp. 74. doi: 10.1016/j.bcmd.2017.09.008.

9. Galochkin V.A., Cherepanov G.G. Natural resistance: Difficulties of identification, problems, and ways of their solution. Probl. Biol. Prod. Zhivotn., 2013, no. 1, pp. 5-29. (In Russian)

10. Kolesnik E.A., Derkho M.A. Involvement of cholesterol, progesterone, cortisol and lipoproteins in metabolic changes during early ontogenesis of broiler chicks of an industrial cross. S- $\mathrm{kh}$. Biol. [Agric. Biol.], 2017, vol. 52, no. 4, pp. 749-756. doi: 10.15389/agrobiology.2017.4.749eng.

11. Kolesnik E.A., Derkho M.A. About participation of pituitary-adrenocortical hormones in regulation of blood cellular pool in chicken-broilers. Probl. Biol. Prod. Zhivotn., 2018, no. 1, pp. 64-74. doi: 10.25687/1996-6733.prodanimbiol.2018.1.64-74. (In Russian)

12. Novikova M.V., Lebedeva I.A., Drozdova L.I. Reducing the risk of reproductive system pathology in cocks by using the Monosporin probiotic. Ptitsa Ptitseprod., 2018, no. 3, pp. 56-57. doi: 10.30975/2073-4999-2018-20-3-56-57. (In Russian)

13. Klyatskaya Yu.V. Comparative morphology of the immunity organs in White Leggorn P-46 chickens influenced with different doses of "Combiolax and "Suvar" preparations. Extended Abstract of Cand. Biol. Sci. Diss. Saransk, 2008. 20 p. (In Russian)

14. Turitsyna E.G. Estimation of the metabolic activity of leukocytes in poultry during the postnatal ontogenesis and under viral antigenic influences. Agrar. Vestn. Urala, 2009, vol. 61, no. 7, pp. 7679. (In Russian)

15. Kletikova L.V. The importance of monitoring the level of cationic proteins in chickens under the conditions of industrial poultry farming. Morfologiya, 2014, vol. 145, no. 3, pp. 94. (In Russian)

16. Drobot G.P., Zabiyakin V.A., Stepanova A.E., Smolentsev S.Yu. Dynamics of cytochemical indicators of pseudoeosinophiles in the blood of guinea fowls. Ross. S-kh. Nauka, 2017, no. 1, pp. 42-44. (In Russian) 
17. Minzuk T.V., Kavtsevich N.N. Bactericidal cationic protein in the leukocytes of marine mammals. Vestn. Murm. Gos. Tekh. Univ., 2013, vol. 16, no. 3, pp. 506-511. (In Russian)

18. Owen J.C. Collecting, processing, and storing avian blood: A review. J. Field Ornithol., 2011, vol. 82, no. 4, pp. 339-354. doi: 10.1111/j.1557-9263.2011.00338.x.

19. Mulisch M., Welsch U. (Hrsg.). Romeis - Mikroskopische Technik. Berlin, Heidelberg, Springer Spektrum, 2015. xviii, 603 p. doi: 10.1007/978-3-642-55190-1. (In German)

20. Markaki Y., Harz H. (Eds.). Light microscopy. Methods and protocols. In: Methods in Molecular Biology. New York, Humana Press, 2017, vol. 1563. 285 p. doi: 10.1007/978-1-4939-6810-7.

21. Kirillova I.A., Kirillov D.V. Reproductive biology of Platanthera bifolia (L.) Rich. (Orchidaceae) on its northern habitat boundary (Komi Republic). Vestn. Tomsk. Gos. Univ. Biol., 2017, no. 38, pp. 68-88. doi: 10.17223/19988591/38/4. (In Russian)

22. Belyakov A.V. The role of metabotropic glutamate receptors of group I in the formation of tolerance of brain neurons to hypoxia. Extended Abstract of Cand. Biol. Sci. Diss. St. Petersburg, 2010. 22 p. (In Russian)

23. Komarova A.S. Changes in the optical density of myosymplast nuclei during embryonic development. In: Voprosy morfologii XXI veka. Vypusk 3: Sbornik nauchny trudov "Aktual'nye voprosy prepodavaniya morfologicheskikh disciplin s ispol'zovaniem sovremennykh tekhnologii. Fundamental'nye i prikladnye problemy gistologii" (220 let so dnya rozhdeniya professora MKhA K.M. Bera) [Problems of Morphology in the 21st Century. Issue 3: Collection of Scientific Papers "Urgent Problems of Teaching Morphological Disciplines using Modern Technologies. Fundamental and Applied Problems of Histology" (On the 220th Birth Anniversary of Professor K.M. Baer)]. Odintsova I.A., Kostyukevich S.V. (Eds.). St. Petersburg, Izd. DEAN, 2012, pp. 60-62. (In Russian)

24. Dimitrov V., Georgiev G. Study behavior of certain parameters affecting accuracy of geometric shape of the workpiece using photogrammetry. Int. Conf. on Technics, Technologies and Education ICTTE 2013. Oct. 30-31, 2013. Yambol, Bulgaria, 2013, pp. 1-8. Available at: https://sites.google.com/a/trakiauni.bg/ictte-2013/.

25. Muzhikyan A.A., Ivanov V.S. Features of the histological structure of thyroid gland in a dog and C-cell morphology in different stages of ontogeny. Aktual. Vopr. Vet. Biol., 2015, no. 3(27), pp. 12-21. (In Russian)

26. Sokolova I.B., Polyntsev D.G. The efficacy of mesenchymal stem cells used for the improvement of cerebral microcirculation in spontaneously hypertensive rats. Cell Tissue Biol., 2017, vol. 11, no. 5, pp. 343-348. doi: 10.1134/S1990519X1705008X

27. Nagoev B.S. Kationnyj belok leikotsitov i ego znachenie. Metodicheskie ukazaniya [Cationic Protein of Leukocytes and Its Importance. Methodical Guidelines]. Nalchik, Izd. Kabard.-Balkar. Gos. Univ., 1982. 68 p. (In Russian)

28. Kudryavtsev A.A., Kudryavtseva L.A., Privol'nev T.I. Gematologiya zhivotnyh i ryb [Hematology of Animals and Fish]. Moscow, Kolos, 1969. 320 p. (In Russian)

29. Campbell T.W., Grant K.R. Clinical Cases in Avian and Exotic Animal Hematology and Cytology. Ames, Iowa, Wiley-Blackwell, 2010. 392 p.

/ Для цитирования: Колесник Е.А., Дерхо М.А., Лебедева И.А. Комплексная морфофизиологическая характеристика иммунного лизосомального катионного белка лейкоцитов в раннем онтогенезе бройлерных кур // Учен. зап. Казан. ун-та. Сер. Естеств. науки. 2019. - Т. 161, кн. 3. - С. 440-458. - doi: 10.26907/2542-064X.2019.3.440-458.

For citation: Kolesnik E.A., Derkho M.A., Lebedeva I.A. Comprehensive morphophysiological description of the immune lysosomal cationic protein of leukocytes in the early ontogeny of broiler chickens. Uchenye Zapiski Kazanskogo Universiteta. Seriya Estestvennye Nauki, 2019, vol. 161, no. 3, pp. 440-458. doi: 10.26907/2542-064X.2019.3.440-458. (In Russian) 